\title{
LA INVENCIÓN DE UN AUTOR: ESCRITURA Y PODER EN EDGARDO RODRÍGUEZ JULIÁ
}

POR

\author{
RUBÉN RÍOS ÁVILA
}

Edgardo Rodriguez Juliá es de los narradores caribeños recientes más prolíficos y ambiciosos. Desde 1974, cuando apareció La renuncia del héroe Baltasar, ha publicado ya ocho libros: dos novelas sobre el siglo dieciocho - una de ellas ominosamente extensa, ya que se presenta a su vez como la primera entrega de una trilogía que aún no se ha completado- cuatro colecciones de crónicas del Puerto Rico moderno desde el inicio de la era muñocista hasta los asesinatos del Cerro Maravilla, un detenido estudio crítico de José Campeche, el primer pintor puertorriqueño de la era colonial y Puertorriqueños, una crónica sobre el desarrollo de la pequeña burguesía isleña a partir de las imágenes de unálbum de fotografías. A esto habría que añadirle una participación asidua en la prensa local, donde sus crónicas agudas e iconoclastas aparecen con bastante regularidad en las revistas dominicales, así como ensayos más académicos en varias revistas universitarias de dentro y fuera del país. ${ }^{1}$

Me parece que esta producción se ciñe a un proyecto narrativo que enlaza las novelas con las crónicas para producir una textualidad, o para usar un nombre más apropiadamente arcaico - por el vínculo que trazan estos textos con la tradición de la crónica de la conquista y la colonia - una relación armada por un autor que se proclama y a la vez se desvanece en su escritura. Estos comentarios son una exploración de la construcción de esa figura, y un intento de nombrar sus coartadas.

${ }^{1}$ En adelante citaré de las siguientes ediciones: La renuncia del héroe Baltasar ( Río Piedras: Editorial Antillana, 1974); Las tribulaciones de Jonás (Río Piedras: Ediciones Huracán, 1984); La noche oscura del niño Avilés (Ediciones Huracán, 1984); El entierro de Cortijo (Ediciones Huracán, 1985; Una noche con Iris Chacón (Río Piedras: Editorial Antillana, 1986); Campeche o los diablejos de la melancolta ( San Juan: Instituto de Cultura Puertorriqueña, 1986; Puertorriqueños: Álbum de la sagrada familia puertorriqueña a partir de 1898 (Madrid: Editorial Playor, 198)9; El cruce de la Bahta de Guánica (Editorial Cultural, 1989). 


\section{MODELOS PARA ARMAR UN PAIS NATAL}

Su capacidad de producción, unida a su talento indiscutible para la indagación sagaz de los modos de lo puertorriqueño, le ha conferido a Rodríguez Juliá un aura de ubicuidad que para algunos lo convierte en el "enfant terrible" de la irreverencia y para otros en nada menos que la conciencia del Puerto Rico contemporáneo. Semejantes epítetos resultarían incómodos para cualquier escritor, pero hay que decir que en su caso nunca antes había habido un autor que pudiese ser descrito tan oportunamente como un "puertorriqueñólogo", si se me permite el término bastante estrafalario. Desde luego, en un país donde la preocupación ontológica por la identidad cultural, etnológica y política ha tenido visos obsesivos desde El Gíbaro de Manuel Alonso hasta La guaracha del macho Camacho. pasando por el Insularismo de Pedreira, pedirle cuentas a un autor por su insistente preocupación nacional es, no solamente anti-histórico, sino sencillamente impertinente. Lo que quizás sorprenda a algunos en el caso de Rodríguez Juliá es su reclamo tan diverso de autoridades a la hora de justificar sus desentrañamientos e indagaciones. Mientras en sus novelas construye frescos desmesurados y deslumbrantes que intentan conjurar los inicios de la cultura puertorriqueña en el siglo dieciocho mediante la reescritura, entre tierna y paródica, de las crónicas de la época, en sus crónicas modernas intenta capturar, o más aún, fijar, la multiplicidad de códigos, el conjunto de hablas que componen el mosaico del Puerto Rico contemporáneo mediante la observación aguda del comportamiento de las muchedumbres en diversos rituales públicos, desde los entierros oficiales y populares de próceres y músicos hasta los encuentros religiosos y los espectáculos de cabaret. Para enfocar debidamente su ojo crítico, el escritor asume los saberes más diversos, y se convierte alternativamente en etnólogo, historiador, cronista, crítico literario, crítico de la pintura, crítico y teórico de la fotografía, comentarista deportivo, aspirante a pornógrafo, humorista, consejero espiritual, y otras cosas, quizás con la excepción de politólogo, hasta la fecha. Se puede decir sin temor a exagerar que a este cronista nada puertorriqueño le es ajeno, y que casi cualquier estrategia investigativa le es familiar.

También puede decirse que ha habido pocos escritores puertorriqueños más ambiciosos en su proyecto literario, que sin duda linda por un lado con la vasta diversidad de discursos de un Alejandro Tapia o con la periférica mirada diagnóstica de un Manuel Zeno Gandía en sus Crónicas de un mundo enfermo. El único otro escritor contemporáneo comparable en el aliento de su ambición es Luis Rafael Sánchez, pero en Sánchez la orfebrería de la escritura, la depuración formal de cada uno de sus textos, sobre todo a partir de En cuerpo de camisa, lo lleva a cuajarlos a fuego lento. Tuvimos que esperar más de diez años por su segunda novela, mientras que Rodríguez Juliá exhibe un virtuosismo de entusiasmo casi deportivo, entusiasmo que inclusive no le teme al desarreglo algo desaliñado de algunos de sus textos, o a la desmesura barroca más delirante, como en el caso de La noche oscura del niño Avilés. 
Si en Luis Rafael Sánchez Puerto Rico encuentra a su gran ventrilocuo, al autor capaz de conjurar el conjunto de sus acentos para internalizarlos en textos que se proponen como rapsodias polifónicas de la voz popular, en Edgardo Rodríguez Juliá Puerto Rico encuentra a su fiscal más severo, como si el proceso de sus indagaciones lo condenara a la constatación reiterada de la renuncia, la falla, la debilidad, la duplicidad y la incompletez que él descubre como constitutivas de la historia puertorriqueña. En el reverso de ambos se encuentra René Marqués, quien es con toda probabilidad el antecesor más inmediato de la idea que ambos se hacen de un escritor. Mientras en los cincuenta y los sesenta René Marqués reinó en Puerto Rico como una especie de super escritor: dramaturgo, ensayista, cuentista, novelista, periodista, acaparador de los premios del Ateneo, y fiscal indiscutible de lo que él entendía como nuestra vergonzosa debilidad histórica, ese espacio, según él lo configuró, está ahora compartido por muchos escritores, pero quizás sobre todo por Sánchez y Rodríguez Juliá. De Marqués, Sánchez recibe -y uso el término sin implicar una deuda mecánica y simplistamente generacional entre un escritor y otroel imperativo del virtuosismo formal, de llevar el drama, la narrativa y la ensayística por los caminos más avezados del riesgo técnico. Rodríguez Juliá recibe en cambio el imperativo ético, esa conciencia de la escritura como la hermenéutica del alma nacional. Ambos pueden leerse comoengendros poderosos y en última instancia parricidas de ese modelo de escritor que René Marqués protagonizó hasta que la aparición de su úl tima novela, La mirada, tuvo la mala suerte de coincidir con la aparición de La guaracha del macho Camacho en 1973. Ese proyecto marquesiano, que tiene a su vez sus antecedentes másimportantes en Pedreira, Tomás Blanco y la ensayística del treinta, definía al autor puertorriqueño como a un Prometeo de la cultura, el albacea del fuego sagrado, al mismo tiempo que un Atlas cargando forzudamente sobre sus callosas espaldas el peso de un conato de nación, un peso que el país mismo no defendía por ser presa de la debilidad colonial.

La obra de Luis Rafael Sánchez es en gran medida un intento de aligerar ese enorme peso, y la multiplicidad de narradores que proliferan en sus textos, enajenados los unos de los otros por estar absortos en sus monólogos delirantes, disemina esa autoritaria voz autorial, tan empecinadamente entronizada en el centro de la institución puertorriqueña de la literatura. En los textos de Sánchez las voces del pueblo funcionan con la fuerza de un conjuro, y aunque el "cuentista" trata todavía de dominar el espacio de su escritura y hay que decir que a menudo lo logra, las voces irrumpen con su energía disonante, con la interferencia del ruido, amenazando con destruir el recinto sagrado del autor y abrir las compuertas de una textualidad irrepresivamente diseminada. La textualidad marquesiana no pudo nunca conciliar su recurrente fuerza erótica con su voluntad casi programática de fundar una racionalidad nacional, y por eso produjo textos pesadamente moralizantes y reprimidos, asfixiados por un andamiaje alegórico que termina aplastando su sustrato libidinal. Los textos de Sánchez, por el contrario, no le temen a encarnar el "performance" ritual del 
deseo, ni de ubicar en su apertura irrepresiva ese territorio hasta ahora escamoteado de la representación cultural. ${ }^{2}$

Rodríguez Juliá parece aferrarse en sus textos a lo que llamaremos el espacio autorial -esa "distancia crítica" que a la vez le delimita una autofiguración y lo mantiene a raya - y sus entusiasmos, o la fuerza seductora de su tema obsesivo no logran nunca derrumbar del todo el recinto sagrado, el lugar santísimo de donde emana su autor-idad, que se abroga el derecho de organizar el mosaico de voces que su oído capta en una suerte de mapa acústico, delineando la topografía de registros, jergas, dialectos y acentos de clase con el dedo magisterial que separa y discierne. Uno de los momentos más cautivantes de La noche oscura del niño Avilés es el episodio de la orejuda, una extraña habitación en forma de oreja que el malvado obispo Larra mandó a construir para colocar allí al niño Avilés, un engendro deforme que el pueblo convierte en su símbolo más poderoso. ${ }^{3} \mathrm{El}$ obispo logra aumentar el sonido del llanto del niño hasta convertir la habitación en una portentosa caja de resonancias. El llanto adquiere proporciones míticas, $y$ cunde el rumor de que el niño Avilés es un endemoniado. Esa manipulación del sonido, de la voz, en este caso del llanto inocente de un niño que simboliza "el pueblo", adquiere la fuerza emblemática de todo un discurso narrativo que a lo largo de las novelas y las crónicas funciona como una oreja hiperbólica, atenta siempre a la amplificación de los registros. La hipérbole, que por lo regular raya en la parodia, en la caricatura o en lo grotesco, desviste la retórica populista de todo gesto mitificador. La retórica del discurso es esa aparatosa caja de resonancias, la orejuda, que construye su autoridad a partir de la amplificación y la distorsión, y los rituales con los que un pueblo constituye su imagen son siempre sometidos a ese proceso desmitificador, como si al invocarse se invalidaran siempre como instrumentos posibles de revelación del ethos nacional.

En el interior de la orejuda se encontraba una indefensa criatura deforme, el niño Avilés, que más que una figura del pueblo funciona en la novela como una

${ }^{2}$ El mismo Sánchez traza elocuentemente la guardarraya que lo separa del ideario de su antecesor:

Para ese público multiforme, que mimó su trabajo y no le esca timó ni incienso ni aplauso, René Marqués esbozó un esquema moral que podriamos llamar, tentativamente, patriologta, y cuyos principios señalados, recurrentes, se desprenden del rápido examen de sus textos: la armonía de unas costumbres asentadas en el señorío respetuoso y noble, la clarificación y propuesta del nacionalismo como una pulcra flexión del cristianismo, la ausencia de tensiones, roces y laceraciones entre los sirvientes y los servidos, el clamor por la vuelta a la tierra. Y, sobre todo, el viaje trágico al pasado, viaje empeñado en el rescate de una utopia perdida o quebrada por la llegada de los bárbaros, para utilizar una categoria suya queridísima", en "Las divinas palabras de René Marqués". Sin nombre 3 (1979) 12.

Véase también la imprescindible lectura de Ancadio Díaz Quiñones: "Los desastres de la guerra" en El almuerzo en la hierba: Lloréns Torres, Palés Matos, René Marqués (Río Piedras: Ediciones Huracán, 1982).

${ }^{3}$ El niño Avilés de hecho existió, y era un niño deforme y sin extremidades que fue llevado a la iglesia ante el Obispo Arizmendi y fue pintado por Campeche. Rodríguez Juliá describe el cuadro de Campeche en "Los diablejos de la melancolia". 
artimaña de la autoridad para fabricar una imagen. Esa habitación que lo esconde no es otra cosa que un emblema del discurso que se lo inventa. ¿Quién habita el recinto sagrado? ¿Con qué ropaje puede reconocerse ese albacea del arca de la alianza, cifrador por excelencia del ethos nacional? Irónicamente, Rodríguez Juliá, el más prolífico de los narradores puertorriqueños, es también el más obsesivamente enfrascado en la búsqueda de su identidad autorial. Más que prolífica, su obra es una búsqueda proliferada de su propio centro, y el intento de fijar en sus textos ese rostro inasible de Puerto Rico funciona también, recíprocamente, como el intento de fijar el rostro del autor posible que lo pueda nombrar.

\section{SOMBRAS NADA MÁS}

Se trata de una textualidad abocada a la apertura, pero nostálgica del centro que la convierta en obra, en un tejido acabado y regido por una ejemplaridad virtual que remita a un sujeto creador. ${ }^{4}$ Todos estos textos se presentan como la indagación de un enigma, que puede ser el negro Baltasar, el niño Avilés, Cortijo, Muñoz Marín, Iris Chacón, o la utópica Nueva Venecia, pero en todos estos casos sustituibles el foco se desplaza también hacia el invocador del enigma como el otro, y quizás como el verdadero centro oscuro de la narración.

En el arranque de La renuncia del héroe Baltasar, el profesor Alejandro Cadalso, narrador principal de la novela, nos dice:

$\mathrm{Si}$, Baltasar Montañez es un enigma que debe reclamar nuestra atención, nuestra conciencia historica y nuestro estudio. Y ello porque este enigma, esta figura que cruza nuestra historia como un celaje oscuro, tiene mucho que decir, desde la lejanía de los siglos, sobre nuestra condicion humana. ${ }^{5}$

Pocas palabras recurren más en estos textos que "enigma", "oscuro", "oscuridad", "noche oscura". El gesto autorial predominante es la develación, la iluminación de los espacios opacos de lo que el texto, entre paródica y gravemente llama "la condición humana". En el caso de La renuncia del héroe Baltasar, la develación gira alrededor de la figura de un negro imaginario que a fines del siglo dieciocho

4 Barthes precisa la distinción entre obra y texto:

El texto se acerca, se prueba, en relación con el signo. La obra se cierra sobre un significado. Se pueden atribuir a este significado dos modos de significacion: o bien se le pretende aparente, y la obra es, en este caso, objeto de una ciencia de la letra, que es la filologia; o bien este significado es reputado porsecreto, último; hay que buscarlo, yla obra depende entonces de una hermenéutica, de una interpretación (marxista, sicoanalítica, temática, etc.); en suma, la obra funciona ella misma como un signo general y es normal que figure una categoría institucional de la civilización del Signo. El texto, por el contrario, practica un retroceso infinito del significado, el texto es dilatorio; su campo es el del significante "De la obra al texto".

En iPor dónde empezar? (Barcelona: Tusquets, 1974) 74.

${ }^{5}$ Rodríguez Juliá, La renuncia del héroe ..., 7. 
llega a convertirse en Secretario de Gobierno al casarse con la hija blanca del anterior Secretario. Esto lo logra mediante una cadena de malévolas tretas el maquiavélico obispo Larra para mantener apaciguados los intentos de revuelta de la mayoritaria población negra de la colonia. Baltasar es una invención del Estado para mantener el balance del poder, y la novela es la historia de su victimización, pero también de su resentimiento y de su eventual locura.

El enigma de Baltasar procede de su misteriosa renuncia al poder. Primero renuncia a ser un héroe de la resistencia negra, a lo que parecía destinado por ser el hijo de un rebelde cimarrón, y luego renuncia a la gobernación, después de que el Obispo se encargara de proveer las circunstancias para la consolidación de su puesto. En su locura, Baltasar se entrega a la construcción de una monstruosa fosa de trampas que serviría para proteger las fortificaciones de San Juan, construcción que él llama "El jardín de los infortunios", y que funciona en la novela como un espacio utópico y delirante. Envenenado por el rechazo de todos, que lo ven como la personificación de la impostura, inclusive rechazado por su esposa, que rehúsa acostarse con un negro, se dedica a coreografiar las orgías más desenfrenadas y refinadas que puedan imaginarse. Estas orgías son a su vez dibujadas por el arquitecto leproso de la corte, que las ilustra con la meticulosidad de los grabados de los libros del marqués de Sade.

Ya en esta primera novela se encuentran las coordenadas de lo que me parece que es la estructura rectora de la textualidad en Rodríguez Juliá. E1 gesto fundacional con que el autor intenta establecer a Puerto Rico desde el dieciocho como entidad cultural, pero sobre todo como sujeto de la escritura, es el gesto de la ilegitimidad. Baltasar es un hipócrita ante los negros, un hipócrita ante el Estado, y un ser condenado a la duplicidad. No puede aspirar al poder, porque el poder en esta escritura emana de la legitimidad, de la pureza o de la naturalidad, y Baltasar es un ser hŕbrido, equívoco y perversamente urbano. De manera que la construcción esmerada de un héroe ficticio que remeda en su discurso de una manera juguetonamente paródica la retórica solemne de la oratoria dieciochesca no sirve para construir un mito. La construcción del mito está minada de entrada por la impotencia de su protagonista. Si el viaje de Rodríguez Juliá al siglo dieciocho tiene como encomienda ética la búsqueda de un principio rector, de un origen genealógico del ethos nacional, la figuración que produce ese entrecruzamiento de horizontes históricos sólo sirve para engendrar un monstruo. Entiéndase aquílo monstruoso en su acepción barroca. Baltasar es monstruoso como un hipogrifo, como un Segismundo; es un ser de una especie y otra, un engendro de dos voluntades encontradas eirreconciliables, pero en este caso el engendro no se resuelve como los misterios escolásticos de Calderón, al convertirse en un símbolo de la doble naturaleza humana, sino que persiste como engendro, cifrado en su misma peligrosidad. ${ }^{6}$

- Sobre el tema del monstruo en el barroco (y en La vida es sueño en particular), de pertinencia en la poética de La renuncia del héroe Baltasar y La noche oscura del niño Avilés, es de utilidad el estudio de Roberto González Echevarría "El Monstruo de una especie y otra". Co-textes 3 (Montpellier,1982). 
Un subalterno que accede al poder, y que no logra ni reivindicar su clase ni olvidarse lo suficiente de ella como para poder gobernar sin culpa tiene como única respuesta posible a su dilema la renuncia al poder. No obstante, no se trata de renunciar para reintegrarse al espacio del subalterno, sino para acceder a otro espacio, que es el espacio de la imaginación pura y enajenada de la razón, el espacio de la locura. El jardín de los infortunios funciona como un emblema de los productos de la imaginación, como una goyesca pesadilla de la razón. Igualmente, las orgías ilustradas por Juan Espinosa, el arquitecto leproso, son un intento de darle autoridad estética al deseo desvariado, como si el sexo puro fuese el consuelo de los derrotados o de los resentidos, y es en ese espacio del deseo desvariado que prolifera la escritura de esta novela, como si la imposibilidad de constituirse en paradigma del poder y producir un verdadero "héroe" dejase abierto el camino de la perversión como la única salida posible.

Los desvarios de Baltasar son un emblema del espacio de la escritura y del arte en la política del texto. Al igual que para Baltasar, el acceso al espacio de la imaginación implica para la figura del autor una abdicación del poder, una renuncia a la viabilización de su lenguaje en las estructuras del orden institucionalizado de la política. Como veremos en el transcurso de nuestra discusión, un escritor es para Rodríguez Juliá una especie de prócer afásico y melancólico, enajenado del espacio de la acción efectiva, condenado a las elucubraciones de su mente solitaria y febril. El enigma que el autor intenta penetrar al explorar la renuncia de Bal tasar es el enigma de ese espacio sagrado de la voz autorial. Baltasar, el otro, la objetivación figurada de una otredad histórica, es el pretexto: el texto, lo que se intenta tejer, es el laberinto que conduzca a ese recinto sagrado y descubra el nexo que asocia o disocia la escritura y el poder.

$\mathrm{El}$ gesto fundacional de esta escritura no se da necesariamente en el viaje al siglo dieciocho o en la identificación con el ethos nacional de por sí. Se da precisamenteen esa identificación de la escritura y el poder. En Hispanoamérica la institución de la literatura no se ha concebido nunca de otra manera. Un continente donde sus escritores regularmente han ocupado puestos ministeriales y diplomáticos, donde el letrado, como en el caso de Vasconcelos, es el diseñador de la política cultural y educativa del Estado, o como en el caso de Bello, el constructor del modelo de nación con que se inaugura el destino de una república, un continente donde la escritura no está reñida con la presidencia, como en los casos de Sarmiento, Gallegos, Bosch, Muñoz Marín, Sarney, y ahora de Vargas Llosa, es un continente donde escribir se ha entendido también como una forma de acceder al poder. Ningún exégeta más autorizado de esa sabiduría del poder que Sarmiento, que en su Facundo fija uno de los modelos más emblemáticos del escritor hispanoamericano. El comienzo de La renuncia del héroe Baltasar es un eco resonante del inicio del prólogo de la edición de 1845 de Facundo: 
¡Sombra terrible de Facundo, voy a evocarte para que, sacudiendo el ensangrentado polvo que cubre tus cenizas, te levantes a explicarnos la vida secreta, las convulsiones internas que desgarran las entrañas de un noble pueblo!. ${ }^{7}$

El viaje arqueológico al pasado para desentrañar la raíz de un enigma y develar el misterio de un pueblo, cifrado en Baltasar, o en Facundo: la estrategia es fielmente paralela, pero el resultado es irónicamente opuesto. En Facundo Sarmiento construye su propia figuración autorial a través de Facundo Quiroga y de Rosas, y ésa es la construcción fundamental del ensayo. Trazando la trayectoria que desemboca en el poder de Rosas, Sarmiento descubre las resquebrajaduras, las fallas que le permiten instaurar su propio proyecto político. El enigma romántico es una estratagema retórica para ubicar en el centro del discurso una voz autorial rectora, colocando detrás o por encima del nombre de Facundo un vacío que sólo puede llenarse con el nombre propio del autor. Todo el texto no es sino la manera de acercarse al saber de ese autor que el texto produce como su más perfecta figuración, y cuyo proyecto es la presentación del escritor como el emblema más poderoso del Estado. Escribir es para Sarmiento una manera de trascender el exilio del poder.

En Rodríguez Juliá, Baltasar no tiene ni la fuerza antagónica ni el encanto seductor que le permita convertirse en la "sombra imborrable" de una centralidad autorial. Tampoco es ese el caso de las otras figuraciones autoriales en La noche oscura del niño Avilés o en las crónicas modernas. En Rodríguez Juliá los personajes siempre están pirandellianamente en busca de un autor, o más bien todos ellos son autores posibles, desplazados en una escritura que se erige para desautorizarlos, y el pivote de esa desautorización es la ausencia de una sombra imitable, de una tradición, aunque sea para desbancarla, o sobre todo para desbancarla. La tradición en Rodríguez Juliá es, para usar su propia frase, una "barranca umbría".

7 Cito por la edición Austral, 1970,240. Para examinar la relación entre escritura y poder en Sarmiento y en la literatura argentina véanse el valioso estudio de Noe Jitrik, Muerte y transfiguración de Facundo (Buenos Aires: Centro Editor de América Latina, 1968), así como el segundo capítulo, "Saber del otro", en Julio Ramos, Desencuentros de la modernidad en América Latina: literatura y polttica en el siglo XIX (México, Fondo de Cultura Económica, 1989) y el ensayo de Carlos Alonso "Facundo y la sabiduría del poder". Cuadernos Americanos 226 (1979) 116-30; Una importante exploración del tema en las letras hispanoamericanas en general se encuentra en The Voice of the Masters: Writing and Authority in Modern Latin American Literature, de Roberto González Echevarría (Austin: University of Texas Press, 1985).

8 "Ahora es imprescindible que me adentre en esa barranca umbría por donde anda mi tradición, esas veladas preferencias y obligaciones manifiestas que han formado nuestro estilo. Machete en mano convertimos la maraña en lectura, ambrosía para melancolicos profesores de la intertextualidad"; "Tradicion y utopía en el barroco caribeño". Extramares: International Magazine of Arts and Letters 1 (Austin, 1989) 3. 


\section{UT PICTURA POIESIS}

En José Campeche o los diablejos de la melancolía, el pintor mulato de la era colonial se presenta como una de las sombras más poderosas, y es claro que está visto como una prefiguración del autor puertorriqueño que Rodríguez Juliá encarna: "La oculta nostalgia de Campeche tiene su fundamento en el porvenir, es una esperanza cifrada en laculminación venidera de la nacionalidad criolla". Ese "porvenir", esa "culminación venidera" se experimenta desde el presente de la narración como nostalgia de un futuro que el pasado no ha logrado conjurar. Irónicamente, en Campeche Rodríguez Juliá diseña la profecía de su sino en el pasado. Ambos son espejos el uno del otro reflejando una duplicidad irresuelta, que los condena al doblez, a la ilegitimidad. La melancolía de Campeche, que Rodriguez Juliá ausculta hábilmente en el gesto equivoco del retrato del gobernador Ustáriz o en el semblante sufriente del retrato del niño Avilés es el producto de un desfase entre la utopía y la realidad, entre la vida y la obra, entre los emblemas con que el pintor intenta conjurar el poder y la ausencia de su mundo mulato y de su gente en sus cuadros. Podría decirse que Rodríguez Juliá escribe para llenar esos dos vacios en la obra de Campeche, que su obra es un intento por devolverle al escritor fundacional del país, que es Campeche, cuya emblemática, nos dice Rodríguez Juliá, "es una escritura pictórica", la simetría entre el pueblo y la utopía, entre el Estado y el país. En la posibilidad de configurar una escritura que logre identificarse con el subalterno, sin por ello abandonar su conexión con el poder, está el secreto de la balanza. Pero para ello tendría que cuajarse un texto que fuese simultáneamente auténtico y ceremonial, privado y oficial, individual y gestual, utópico y populista. Es de esa imposibilidad, (que podría interpretarse como la imposibilidad de reescribir el Facundo, o aún Ariel, es decir, de reescribir la tradición de una ensayística fundacional que en este discurso se declara exhausta e improbable), que surge el espacio en blanco que marca el espacio autorial en todos estos textos, como si cada uno de ellos aspirara a nombrarlo infructuosamente.

En La noche oscura del niño Avilés se aborda sistemáticamente el intento de fundar una utopía del origen puertorriqueño. La Nueva Venecia sería esa ciudad libertaria y utópica donde se funda una mítica nación cimarrona que, sin embargo, nos dice el narrador, ha desaparecido de la memoria colectiva del pueblo. La novela, desmesurada y elíptica, es el intento de recuperar esa memoria perdida mediante la invocación de una memoria trascendental, mítica y ritual, que logre devolverle al pueblo el contacto con sus orígenes perdidos. Sin embargo, el mayor impedimento con que se enfrenta el lector a la hora de experimentar esa memoria mítica es una implacable estrategia digresiva que

\footnotetext{
${ }^{9}$ Rodriguez Juliá, Campeche, 24.
} 
una cadena de figuras autoriales le impone al proceso de lectura. ${ }^{10} \mathrm{El}$ narrador compite con las crónicas de Gracián, el secretario del represivo obispo Trespalacios, las crónicas de Julián Flores, criollo simpatizante de la causa negra que firmó sus testimonios con el nombre de El Renegado, y una cadena de cronistas de turno que someten los acontecimientos a repetidas mediaciones. Hay a su vez manuscritos apócrifos de El Renegado, un supuesto diario del obispo Trespalacios y, como si esto fuera poco, a medida que vamos leyendo la novela, un lector comentarista llamado Alejandro Juliá Marín nos va distrayendo con otra cadena alterna de notas al calce que reinterpreta, contradice o puntualiza, acontecimientos cruciales de la narración al mismo tiempo que va espejeando la novela en una prosa poética entre paródica y sublime.

La obra se mueve pesadamente, sometida al embudo asfixiante de la elipsis barroca. Carpentier y Lezama Lima son aquí los intertextos cruciales, pero el barroco de Rodríguez Juliá no posee ni la depurada objetividad emblemática del barroco carpenteriano, tan fundado en la más rigurosa reconstrucción arqueológica del pasado, ni tampoco posee la fuerza visionaria del barroco lezamiano, que trasbasa la tiranía cronólogica para habitar lo que Lezama llama el reino de las eras imaginarias. Aquí el barroco no logra desembarazarse lo suficiente de la parodia o de la conciencia del falseamiento, y la elipsis no produce el espejismo del centro. El momento grandioso de la narración, cuando El Renegado desciende al reino del caudillo rebelde Mitume enviado por Obatal, y se encuentra con un inefable paraíso de la lujuria, es la cueva de Montesinos de esta novela, e indudablemente logra una intermitenteluminosidad, pero está siempre demasiado cerca de lo grotesco como para producir la epifanía mítica, la pintura de la escritura o escritura pictórica que la novela parece buscar. Inclusive el punto focal de la narración, el rescate del niño Avilés, que es un símbolo de la liberación cimarrona, y la construcción de una leyenda diabólica que lo convierte en endemoniado para alejar al pueblo de su magnetismo liberador, está desperdiciado al principio de la narración, como si en el montaje de la estructura narrativa no se contemplara la posibilidad del suspenso o de la

\footnotetext{
10 Una buena parte de la nueva narrativa puertorriqueña puede entenderse como el intento de fundar un discurso mito-poético que regenere la memoria exhausta de una colectividad amnésica. Un buen ejemplo es el cuento "Papo Impala está quitao", de Juan Antonio Ramos, donde un narcomano desarrolla su extraviada disertación sobre la salsa -la música representativa del lumpenato mulato- y su memoria destruida por la adicción no le permite recordar el nombre de su músico favorito, un músico que no tiene que endrogarse para "tocar" bien. En esa dicotomía entre la intoxicación artificial del narómano y la intoxicación dionisíaca, ritual, de la salsa, se crea la melancolía del personaje, inepto para encontrar en la música su memoria mítica perdida. El narrador entiende su oficio como un acto de regeneración de "performance" que permita reconstruir esa memoria perdida. Escribir se convierte de esta manera en un acto entre platónico y chamánico, abocado al proyecto de la restauración de la voz perdida de la raza. En la ruta tortuosa de las digresiones de Papo Impala s6lo persiste el leit motiv del recuerdo de un músico "puro" que no se puede recuperar.
} 
intensificación dramática, que serían resortes retóricos posibles para la epifanía. Esta novela, más que sobreescrita, esta sobreleída. Hay un abarrotamiento de cunas metalingüísticas interfiriendo el progreso de la narración, como si un lector obsesivo la detuviese constantemente para interrogarla.

El nombre más resonante de este lector privilegiado es, como dijimos anteriormente, Alejandro Juliá Marín, y ya lo habíamos visto en La renuncia del héroe Baltasar, donde el profesor Alejandro Cadalso, académico universitario de la generación del treinta y principal historiador de Baltasar Montañez, lo usaba como testigo literario de la época citando fragmentos de sus obras dramáticas. Alejandro Juliá Marín funciona como una fórmula del proceso de producción y recepción de la textualidad a medida que ésta se va generando, como un contrapunto metalingüístico. El nombre propio, que comparte con Cadalso, alude a Alejandro Tapia y Rivera, y sitúa la centralidad autorial en la era colonial, lo que es una manera de reclamar autoridad sobre el tiempo de la mitificación. Por otra parte los apellidos Juliá Marín aluden al tío abuelo del autor, Ramón Juliá Marín, autor de dos novelas, Tierra adentro (1911) y Lagleba (1912), ambas el testimonio escandalizado de la burguesía agraria isleña al ser desplazada por lainvasión norteamericana. De manera que hay en este nombre compuesto una yuxtaposición de momentos históricos que se consideran cruciales para el desarrollo de la cultura puertorriqueña: la consolidación de la sociedad colonial en el siglo diecinueve y la ruptura o el trauma, como lo llama sicopatológicamente Manrique Cabrera, de la invasión norteamericana. ${ }^{11}$ Alejandro Cadalso es otro alter ego autorial, y representa la generación del treinta, la primera generación de intelectuales puertorriqueños formada bajo la dominación norteamericana, y la generación fundadora de la ensayística de la ontología del ser nacional. En estas fórmulas compuestas, donde el linaje literario y el linaje familiar se confunden, el autor produce una imagen de la estirpe letrada a la que pertenece, y desde la que desea leerse en sus textos.

En Alejandro Juliá Marín se crea un mirador desde donde atisbar ese espacio sagrado del autor que los textos de Rodríguez Juliá sólo llegan a invocar como un espacio en blanco. Este nombre-legión no existe para llenar ese espacio, sino para nombrarlo, y para convertirlo en el espacio de la nostalgia melancólica de la escritura. Una de las continuas notas al calce, titulada "Estilo del Renegado", y que podría traducirse como "Estilo del Autor", dice lo siguiente:

11 El término "generación del tránsito o del trauma", que acuña Cabrera en su canónica Historia de la literatura puertorriqueña, se ha naturalizado como una manera de dividir la cronología de la literatura y la cultura puertorriqueñas a partir de una fisura o herida fundacional: antes o después de la invasión norteamericana. Podría entenderse la atención que le da Rodriguez Juliá al" dieciocho" como un intento de desviar la atención de esa cronología hemisférica de la historia para proponer un modelo distinto del desarrollo cultural, marcado más por la repetición ritual o el espejeo infinito que por la crisis de la ruptura. La duplicidad, la ilegitimidad, más que la invasion, aparecen como fuerzas constitutivas del espacio cultural. 
Es la posibilidad de la letra en ese recinto donde la voluntad impera. La necesidad queda abolida, y el recuerdo se convierte en presente, actualizándose para perplejidad del lector, goce y travesura del Renegado.

Todo es posible en ese espacio, y el capricho colmado de tristeza prevalece sobre el buen gusto gramatical y los cánones artísticos. De este modo huye del tiempo el cronista - iHuirá de su propia sombra, de su inexorable oficio?-, anhela el espacio perfecto que es añoranza y utopía de la memoria, esa imaginación lastrada por el pasado. ${ }^{12}$

La voluntad marca la posibilidad de la letra. El carisma del escritor está aliado a su capacidad de producir un espacio gratuito, liberado de lo contingente y abierto a la posibilidad infinita. La escritura y sus caprichos rebasan los límites de la obra acabada, perfecta. La escritura está marcada por la proliferación liberadora, pero a su vez esa proliferación la aleja de su centro controlador y la impele a la dispersión. Ese anhelo del "espacio perfecto", donde utopía y escritura coincidan en nombrar el pasado y justificar el oficio del escritor no llega a ser más que "capricho colmado de tristeza". Lo que condena al escritor a la impotencia es precisamente su enajenación de la Historia, del tiempo. En la medida en que huye del tiempo, irónicamente huye de su propia sombra, y renuncia a la posibilidad de que la escritura pueda ser el espacio donde el autor y el poder coincidan..$^{13} \mathrm{El}$ acceso a ese espacio gratuito implica una abdicación, como si la escritura en la postmodernidad no pudiese ya reclamar tan impunemente su espacio en el orden institucional del poder y tuviese que conformarse con sólo ser dueña de su propio recinto. Para escribir, el escritor post-moderno tiene primero que renunciar al poder, pero al hacerlo, ese recinto de la textualidad queda huérfano de centro. La textualidad, abierta, proliferada, y referida más a la máquina de la lengua que a la figuración de un sujeto se resiste a ser obra, a cerrar el círculo y proponerse como ejemplo, como modelo.

\section{VERDADERA HISTORIA}

Sin embargo, el autor en busca de su propia figuración, o más bien de una figuración "propia", en el sentido gálico de "limpia" y en el moral de "correcta", escribe sobre todo para nombrar su sombra, como si al contemplarse diferidamente en su retrato de los tiempos recibiera una imagen trascendida, purificada, de sí mismo. Por eso el autor aquí es sobre todo el cronista, el relator de los tiempos, pero su relato histórico está más interesado en ser verdadero que

${ }^{12}$ Op. Cit.., 76.

13 "La relación tierna de la parodia con su paradigma puede contener la semilla de un estilo historicista pero también vital, donde la textura misma de la prosa evoque no sólo paisajes distantes, sino también modos de pensar que pertenecen a la opacidad de lo histórico. Por otro lado, jamás tuve la pretensión de eso que se conoce como fidelidad histórica. Estas novelas no son historicas. Son fundaciones utópicas que disfrazan de historicismo su textualidad" Extramares, 4. 
histórico, más legítimo que fidedigno. El cronista, como un Bernal Díaz desposefdo y vejado por las autoridades, busca en el amparo de la escritura la relación que le devuelva su autoridad escamoteada. Las crónicas modernas de Rodriguez Juliá intentan capturar la mirada del otro en el ojo contemporáneo, pero al asumir el gesto fundante del cronista, la relación o textualización de los hechos aspira a devolverle de alguna forma a su escritura su autor-idad. La indagación en el siglo dieciocho se proponía marcar las coordenadas de ese gesto. Pero no se puede entender esa indagación como un viaje diacrónico, donde la identidad sea el producto del progreso, del cambio, o de la transformación sucesiva. En este sentido podría decirse que Rodríguez Juliá es un escritor anticinemático. La imagen central de su obra es el retrato, o más modernamente, la fotografía. La colisión de marcos de referencia históricos produce un conglomerado sincrónico y estático que arroja un destino implacable: sólo hemos sido siempre lo que somos ya:

La fotografía exige la pose antes asumida para el retrato. [...] Posar es un acto de fundación. Al posar fundamos nuestra presencia en el mundo, validamos, a través de la imagen, nuestra particular parcela en la realidad. El posar es pronunciar un discurso sobre la personalidad y todo aquello que la sostiene socialmente. ${ }^{14}$

La pose funda en la medida en que fija y trasciende el tiempo, el acontecer accidentadoe indetenible de los hechos. El retrato posee una fuerza emblemática, capaz de conjurar un registro esencial, utópico y ucrónico, donde el mito y el pueblo coincidan en el rostro del autor, haciéndolo verdadero, legítimo. El autor no es una sicología, ni tan siquiera una autografia: es un constructo, una rúbrica controladora que se figura como sujeto para controlar la proliferación del sentido y detener la textualidad desbocada. ${ }^{15}$ Una textualidad en busca de un autor para emblematizar un pueblo en busca de un autor. Ese espacio en la política del Estado le corresponde en esa otra textualidad de la Historia a Muñoz Marín (el último apellido de Alejandro Juliá, el "último" autor), y podría entenderse la escritura como el desfase paralelo entre ambos aspirantes a "autor" con sus correspondientes territorios, como la historia paralela de dos ilegitimidades.

Las tribulaciones de Jonás y El entierro de Cortijo son las crónicas funerarias del muñocismo, como si el texto sólo pudiese referir su ausencia, su muerte, su

14 Rodriguez Juliá, 15.

${ }^{15}$ Ésa es para Foucault la función principal de la figuración autorial en un texto, y la postmodernidad tiende a difuminar esa función proponiendo una textualidad abierta, que no puede remitirse a un origen genealógico. El texto post-moderno se libera de la noción de autor como categoria generadora de la escritura. El autor es más un producto que una condicion del texto. Ver "What is an Author?" en Textual Strategies. Editor, Josué Harari (Baltimore: Jonhs Hopkins University Press, 1979). 
noche oscura. Muñoz Marín es el aspirante a autor condenadoa la contemplación afásica y melancólica de su fracaso. Rodríguez Juliá encuentra en él el alter ego de su escritura, su fantasma, su estrafalaria sombra imborrable. Baltasar Montañez, aquel secretario de la gobernación escindido entre su traición doble a la cimarronería rebelde y al mandato de poder del Estado, está concebido desde el presente dominado por el Puerto Rico de Muñoz. Es ese Estado débil, constitutivamente ilegítimo, el que organiza las encrucijadas de esta textualidad.

Se escribe para aspirar a la pose, y el otro en el fondo existe para construir la pose del que escribe. ${ }^{16}$ En las crónicas modernas ese otro es siempre el pueblo, la muchedumbre, la masa. Las tribulaciones de Jonás es la crónica del Muñoz del pueblo y El entierro de Cortijo es la crónica del pueblo de Muñoz, pero en ambas esa polaridad refleja la tensión básica de la escritura entre el autor y su otro. La inadecuación de los polos es el defecto que marca la escritura. Por eso el narrador, esa figura deseante del autor, aparece siempre en estas crónicas como la presencia alterna, a veces como observador, a veces como colaborador o a veces como antagonista de la muchedumbre o de su representante oficial, Muñoz Marín. En Las tribulaciones ese narrador es el espectador entre anonadado, cautivo y asqueado de Muñoz, oscilando entre el espejo degradado del escritor "pendejo", exiliado del poder, y el escritor indignado, resentido por el poco poder que el modelo del Estado le confiere a sus albaceas, a sus modelos posibles. En El entierro de Cortijo el autor es el narrador escindido entre la ternura y el desvarío, escandalizado en el caserío público Luis Lloréns Torres, la anti-utopía del desarrollismo muñocista, donde el nombre de un poeta modernista dandy, Luis Lloréns Torres, emblematiza irónicamente con su rúbrica la poca capacidad de la literatura de conjurar el espacio grotesco del pueblo. El Muñoz poeta del realismo social, el "Panfletero de Dios", amigo de Palés, el fundador del neo-primitivismo antillanista en que se funda el retorno mítico de Juliá al país natal, y Lloréns, el maestro de Palés, forman una cofradía melancólica: todos son los aprendices de autor de un pueblo que se resiste a ser escrito porque no se siente aludido por ninguno de ellos. El caserío Lloréns Torres, donde velan a Cortijo, el sacerdote del lumpenato mulato y cimarrón, es el espacio ilegible de la anti-utopía, es la escritura proliferada y abierta que sigue resistiéndose a la codificación.

Ese otro de la colectividad puertorriqueña amorfa, contradictoria, siempre a medio camino entre la ternura y el desvarío, es la otra cara del espacio oscuro y silencioso de la escritura. En la escritura el gesto del escritor aspira a depurar su pose a contrapelo de ese ruido, de esa barahúnda. En el pueblo el autor

16 La angustia de no poder conjurar la pose en la escritura está dramatizada en la impotencia de Baltasar. El autor apócrifo Alejandro Juliá Marín describe de esta forma lo que él llama "La mirada del héroe": "Buscaba un gesto que resumiera todo su afán: ejercicios de laberintos sin respuesta. Dibujos que no alcanzaban la precisión del sueño. Cascadas de papel que fatigaban techos lejanos, de los cuales ya no llegaban claras noticias". 
posible (Muñoz, Lloréns, Palés, Juliá) aspira a cifrar el otro de su rostro, y en un gesto recíproco, fundarse. Para el cronista la pluma está cifrada sobre todo en la cámara fotográfica, y se escribe para reducir la linearidad progresiva y metonímica de la narrativa al acto virtual de la instantánea. En el ensayo Una noche con Iris Chacón el escritor describe las vicisitudes de esa pose:

Aquí sentado, perfectamente seducido por mi soledad de voyeur, me encuentro a mitad de camino entre la ensoñación y la observación, indeciso entre el género de la crónica y la crónica de lo venéreo. Es difícil la ecuación: debo testimoniar y a la vez rescatarme de esa turba enemiga allá fuera, celebrar con ellos el cerebro de todos y fundar el mío propio, ahí, sin distracciones, en la perfecta serenidad del silencio oscuro. ${ }^{77}$

¿Para qué sirve el otro, sino para fundar la pose del autor en la "noche oscura" de su vía purgativa, una noche que sólo le promete la revelación de su nombre en el texto, su espacio "mío propio" a cambio de la entrega a su otredad?: en el pueblo se confirma la ecuación que le devuelve su "cerebro celebrado", y esa ecuación es estrictamente erótica, se trata de un acto copulativo, de un antiguo ritual orgiástico, y la inminente aparición de la portentosa Iris Chacón en escena coincide con el descenso al reino oscuro de Mitume, o con el encuentro con el niño monstruo. En Rodríguez Juliá la identificación con el pueblo siempre se da por el lado del deseo desbocado. Al igual que Baltasar, el narrador de Una noche con Iris Chacón sólo puede entender el comercio íntimo con el pueblo por vía de la perversión. ${ }^{18} \mathrm{El}$ pueblo siempre es aquí una variante de la turba, no $\tan$ distante de la muchedumbre que se abalanzaba sobre el unitario en $E l$ matadero de Echeverría, a punto de echar por el suelo el féretro de Muñoz Marin, o tentado de improvisar un soneo sobre la tumba de Rafael Cortijo.

La fijación de la pose se ve constantemente amenazada por la muchedumbre desvariada, que no es sino un reflejo de la textualidad proliferada, y viceversa. Una manera de articular este dilema es la siguiente: Rodríguez Juliá es un autor postmoderno poseído de una nostalgia premoderna. ${ }^{19}$ Su manejo de una

${ }^{17}$ Una noche con Iris ..., 126.

${ }^{18}$ La última colección de crónicas, El cruce de la bahía de Guánica, es una reiteración de este principio. Un narrador observa las muchedumbres que van a bañarse a la playa con los ojos lúbricos de un sensualista incurable, que sólo acierta a ver en el pueblo el objeto de su deseo desbocado. Este narrador recuerda al intelectual inadaptado de Edmundo Desnoes en Memorias del subdesarrollo, con la diferencia de que en este caso no hay revolucion alguna que lo haga sentirse moralmente inferior. Véase mi reseña del libro ("El apetito y el asco") en Puerto Rico Ilustrado, El Mundo, (12 de noviembre de 1989) 20-23. ${ }^{19}$ En su excelente exploración de las coordenadas textuales de La noche oscura Antonio Benítez Rojo describe elocuentemente la encrucijada retórica de la novela, que me parece ilustrativa de una reiterada tendencia de la escritura en Rodriguez Juliá:

Quiero decir que Nueva Venecia, la cimarrona, la que existe en los miasmas nocturnos de los pantanoe al otro lado de San Juan, quisiera ser San Juan; sueña con tener un Capitolio, una 
consciencia de la escritura como textualidad, como apertura y posposición diferida del sentido, lo acerca a una concepción de la cultura que el postestructuralismo de Derrida, Foucault o Lacan ha articulado como el saber (o mejor, el no-saber) de los tiempos. Sin embargo, lo que a falta de un término menos determinista podriamos llamar su "condición caribeña", lo sitúa en un ámbito anterior a la diseminación del sentido, ávido de centro, nostálgico de autor, y esa nostalgia está regida por lo que podríamos llamar el modelo sarmientino del escritor latinoamericano, el letrado cuya función virtual es la educación de su pueblo.

Pero ese autor "fundacional", ejemplo apto de la racionalidad del Estado por un lado, y de la voz del pueblo por otro, sólo es posible cuando el sujeto que produce la escritura se encuentra representado en el pueblo y en el poder. La experiencia de la escritura arroja todo lo contrario, porque los modelos son "defectuosos": el representante oficial del poder en el Estadoes ya un renunciante al poder, un ser equívoco e inauténtico, condenado a la duplicidad, y el pueblo que funda, o el pueblo que lo creó, (la ecuación es practicamente tautológica) es indistinguible de esa misma duplicidad. Ambos, autor y pueblo, deambulan en el limbo de su amnesia crónica, incapaces de restaurar una memoria mítica que le devuelva su voz virtuosa y antigua, una voz que a lo mejor nunca existió. De manera que los textos -l movimiento de la textualidad abierta e irrepresiva, metaforizada en la cadena de modelos para la Nueva Venecia o en la monstruosidad del niño Avilés-proponen un autor para una obra que no existe. El espacio vacío del sujeto de la creación, que aspira más que nada a ser leído por $s u$ pueblo, se desconstruye leyéndose por sus propios fantasmas: Alejandro Juliá Marín, Alejandro Cadalso, José Campeche, El Renegado, Palés, Lloréns, Marqués, o Luis Muñoz Marín: el Renegado Mayor. ${ }^{20}$

El gesto biográfico con que se construye la figura de Muñoz en Las tribulaciones es el equívoco ejemplar de todos estos textos. Hay en la admiración que provoca la biografia del ídolo, del caudillo, cierta dosis de rencor, cierto inconfesado resentimiento. El biógrafo es al mismo tiempo el arquitecto y el asesino de la imagen que edifica en la biografia. El gesto equivoco parte de la distancia cómplice que lo separa y lo atrae de la figura que se intenta reconstruir

Catedral, un Castillo del Morro, una Universidad, una Biblioteca, una Bandera. Por su parte, el niño Avilés, su ojo desesperado y su ojo triste, su deformidad de Minotauro, desea despegarse de su indescifrable retrato y estar acd, en el lugar de cualquier niño; tal vez incluso pasa la noche eterna de su ahistoricidad desvelado por las ganas de someterse a la disciplina del Padre, de la Patria de la Escuela. La isla que se repite: el Caribe y la postmodernidad (Hanover. Ediciones del Norte, 1989) 295.

Texto y obra, proliferación y cierre, deseo y orden se reflejan como espejismos reciprocos en una escritura que desea ser oficial y paródica simultáneamente.

${ }^{20}$ En Las tribulaciones hay un momento emblemático cuando Muñoz le pide a Rodriguez Juliá que lea un texto suyo, que se convierta en su lector, y la narración del narradorautor-personaje es la siguiente: "Le pasé el texto a mi esposa Ivonne, a ella le tocaria ensuciarse las manos con aquel maldito texto del Renegado", 50. 
en su máximo grado de significación, precisamente porque los rasgos que la redondean, los que simulan labio en lagrafía son los que más contundentemente se presentan como constructo, como engendro textual. El texto traza la simetría de esa distancia, como si se tratara del laberinto de una línea recta. El narrador de la crónica desaparece dentro del cuerpo desmesurado del líder, como Jonás dentro de la ballena, para desde alli dentro descubrir los perfiles de su propia figuración. Acaso lo que le da el carácter superlativo a la imagen de un Renegado Mayor sea precisamente su complejidad como síntesis, como suma de los polos: por un lado la voz narrativa y por otro Muñoz. Ésa es la amplificación excesiva y deforme que termina proponiendo la desautorizada voz del cronista, ése el producto máximo de su relación de hechos.

El pueblo tampoco llega a configurarse más allá de sus excesos o sus deformidades, y el autor posible se aleja melancólicamente, disociado de su público, perdido en sus elucubraciones, como aquella noche con Iris Chacón cuando decidió que la celebración de su "cerebro" era preferible a la celebración del espectáculo. Pero la distancia es traicionera y relativa. El narrador se aleja de su héroe derrotado o de su pueblo insuficiente, es decir, se aleja de los objetos de su deseo, para seguir reconociéndose en ellos a la distancia, y ese escritor que aspiraba a encarnar al autor que consignara la inconciencia de su pueblo, termina convirtiéndose en el fiscal entre seducido y escandalizado de su propio inconsciente, un espacio permanentemente insubordinado e indomesticable, donde reinan invictos los monstruos que la escritura no llega a exorcizar. Todo texto le devuelve a un escritor su rostro extrañado, como si fuera un otro, y en Rodríguez Juliá ese otro es el pars natal que se resiste a armarse como un modelo manejable y que se le impone, por el contrario, como su autorretrato más fiel. El aspirante a autor de su pueblo escribe para dejarse escribir por él y para resignarse a decir, como Flaubert decía de Madame Bovary: Puerto Rico soy yo. 
